Araştırma Makalesi / Research Article

\title{
THE CURFEW FOR ELDERLY DURING THE COVID-19 PANDEMIC: DIFFERENT PERSPECTIVES, DIFFERENT HORIZONS
}

\author{
Pelin ÖNDER EROL* \\ COVID-19 PANDEMISİ DÖNEMINDE YAȘLILARA \\ YÖNELİK SOKAĞA ÇIKMA KISITLAMASI: FARKLI \\ BAKIŞ AÇILARI, FARKLI UFUKLAR
}

\begin{abstract}
The aim of this paper is to display different perspectives and different horizons both younger and older people have in terms of curfew for elderly. These measures have been implemented as a mechanism to control the spread of COVID-19. The pandemic caused not only a community health crisis, but also a social crisis due to the restrictions including social distancing for all people and more importantly curfew for the older people. Since the curfew is limited to people over a certain age, it became an issue of intersection of ageist and anti-ageist discourses. By drawing upon Hans-Georg Gadamer's theory of "fusion of horizons", this paper is an attempt to interpret older people's curfew from two distinct horizons, those of ageist and and anti-ageist.
\end{abstract}

Keywords: Gadamer, Fusion Of Horizons, Curfew, The COVID-19 Pandemic, Age Discrimination.

\section{Öz}

Bu çalışmanın amacı, COVID-19 salgının yayılmasını kontrol altına almak için alınan önlemlerden biri olan yaşlıların sokağa çıkma kısıtlamasına dair gençler ve yaşlılar tarafından geliştirilen farklı bakış açılarının ve farklı ufukların bir resmini sunmaktır. Pandemi, sadece bir sağlık krizine yol açmamış; tüm toplum için sosyal mesafelenme ve daha da önemlisi yaşlılar için sokağa çıkma kısıtlaması gibi sınırlamalar nedeniyle aynı zamanda sosyal bir krize de yol açmıştır. Sokağa çıkma kısıtlamasının belirli bir yaşın altındakilerin yanı sıra, belirli bir yaşın

* Doç. Dr., Ege Üniversitesi, Edebiyat Fakültesi, Sosyoloji Bölümü, e-posta: pelin.onder.erol@ege.edu.tr, https://orcid.org/0000-0003-3660-4618.

İntihal Taraması: Bu makale intihal taramasından geçirilmiştir.

Etik Beyan: Bu çalışmanın hazırlanma sürecinde bilimsel ve etik ilkelere uyulduğu ve yararlanılan tüm çalışmaların kaynakçada belirtildiği beyan olunur (Pelin Önder Erol).

Atıf: Önder Erol, P. (2021), The Curfew for Elderly During the COVID-19 Pandemic: Different Perspectives, Different Horizons, 21(2), Abant Sosyal Bilimler Dergisi, s. 207-219, https://doi.org/ 10.11616/basbed.vi.900379.

Makale Gönderim Tarihi: 20.03.2021

Makale Kabul Tarihi: 26.05.2021 
üstündekilerle sınırlanmış olması nedeniyle konu, yaş̧̧ı ve yaşçı karşıtı söylemlerin kesiştiği bir odak halini almıştır. Hans-Georg Gadamer'in "ufukların kaynaşması" kuramına dayanarak bu çalışma, yaşlıların sokağa çıkma kısıtlamasını, yaşçı ve yaşçı karşıtı olmak üzere farklı ufuklar çerçevesinden yorumlamaya yönelik bir girişimdir.

Anahtar Kelimeler: Gadamer, Ufukların Kaynaşması, Sokağa Çıkma Kısıtlaması, COVID-19 Pandemisi, Yaş Ayrımcılığı.

\section{Introduction}

In December 2019, an outbreak of COVID-19 has appeared in China, and it has spread to other continents in early 2020 . For example, it was as late as March the $11^{\text {th }}, 2020$, when the first infected case was officially announced in Turkey. It was also when World Health Organization declared the outbreak as pandemics. The first death due to COVID-19, which was a death of an old male, was reported on March the $17^{\text {th }}, 2020$. It was no accident that the death case was an old person. Globally, higher risk for mortality among the elderly caused by COVID-19 (Jordan, 2020) is thought as a hallmark of the pandemics.

Similar to measures taken in many countries, curfew for citizens who are aged 65 and older during the COVID-19 pandemic was declared on March the $21^{\text {st }}, 2020$, at about $5 \mathrm{pm}$ in Turkey. By doing this, it was aimed at keeping the elderly isolated at their homes. However, for some varying periods, older people are allowed to go out for particular hours. During this period when accompanying discussions around the issue of curfew, especially the young people were arguing that the elderly should stay home for the sake of public health. The idea behind this was mostly a misunderstanding that elderly is the very cause of infection. However, the answer to the question whether it is the elderly who are threating the community health or whether it is the rest of the society who are threating the health of the elderly has been rather confusing for a long time.

A conventional discussion centring on "age" was also echoed in the discourses developed in social media networks (Taşdelen, 2020), which are mostly constituted by younger people (Altın, 2020). On the other hand, elderly had felt constrained by the curfew and besides they had been exposed to those ageist discourses. Unlike younger people who make use of social media, elderly couldn't make their voice fully heard neither for defending themselves against ageist discourses nor for raising their objections for bending the curfew. Simultaneously, the pandemic had also become a scene of intergenerational solidarity for some cases (Ellerich-Groppe, Pfaller \& Schweda, 2021). What is also perceived as ageist by the elderly is the execution of the curfew, and at the same time it 
is the discourse developed by the non-elderly who are blindly stick to the idea that elderly should stay home for the sake of the society. As a result, the meaning co-produced by different perspectives and different horizons arose for one single circumstance, which is just similar to two sides of the same coin. These differences find a large scope in the literature and are identified as cross-generational research. The subject matters of these research are ranging from generations at work (Murray, 2011; Roebuck, Smith \& Haddaoui, 2013), to generational differences in parenting styles (Dubow, Huesmann \& Boxer, 2003; Zervides \& Knowles, 2007), and even to issues related to social media (Leung, 2013; Napoli, 2014).

In order to understand this two-folded meaning, which makes the already existing societal gap for different age groups even deeper, Gadamer's theory of "fusion of horizons" will be drawn upon. By following Gadamer we can argue that meaning creation is a collective action where different horizons may fuse each other and arise as a monolithic meaning.

This paper aims at finding out how one single circumstance can be approached by different perspectives and can form different horizons, which are emerging from the dualism of ageist discourse and the discourse against age-based curfew in the era of COVID-19.

\section{Theoretical Framework}

In his book Truth and Method Hans-Georg Gadamer (2004) proposed that language is a medium to fuse the horizons where "the horizon is the range of vision that includes everything that can be seen from a particular vantage point" (ibid: 301). "The horizon is not the limit of meaning, but that which extends meaning from what is directly given to the whole context in which it is given, including a sense of a world" (Vessey, 2009: 536).

By interpreting different horizons and the possibility of fusion of horizons is a hermeneutic act. "Horizons mark the limits of our understanding as our background beliefs affect what sentences we understand and how we understand them. And horizons take on a particular point of view as the beliefs reflect individual differences" (Vessey, 2009: 537). Among these individual differences, there exists differences created by age effect. Gadamer also pays a special attention to historical consciousness while he is arguing that different historical periods have their own horizons. This implies a sort of period effect, in addition to expected age effect. Nevertheless, present horizon is a part of the historical horizons, in that horizon of today is supposedly fuelled with that of the past.

A possible application of his theory is also consistent with what Gadamer suggests. According to him, hermeneutic is a tripartite venture, the two 
elements of which are understanding and interpreting. However, the third and the most frequently ignored aspect is "application" (Gadamer, 2004: 306).

"(W)e consider application to be just as integral a part of the hermeneutical process as are understanding and interpretation" (ibid: 307).

Besides, not only text in its classical meaning but also language produced in everyday life and the representations of constructed reality can be the unit of analysis in application of Gademer's theory. As a matter of fact, Andersen (2020) argued that even a hermeneutics of algorithms created in digital technologies is possible. Therefore, in this paper, the literature which has been written on the curfew for elderly during the COVID-19 pandemic was reviewed and revisited. As a methodological means, literature review is defined as a process in which as many publications as possible is researched deeply and systematically (Gash, 2000 as cited in Köroğlu, 2015).

Gadamer's philosophical theory of fusion of horizons offers a wide insight. Therefore, the theory should be unboxed in order to make use of it in understanding and interpreting distinct horizons towards the same issue. In this paper, younger people's horizon and older people's horizon about the curfew of the elderly, are fused each other in order to make sense of the dialogue between these groups. According to Vessay (2009: 541), fusion of horizons doesn't necessarily end up with an agreement about the issue; but it may be a shared understanding about it. Instead, it is a dialectic of coexistence and otherness of the issue which is continuously occurring between the past and the present (Tatar, 2018: 153).

From a sociological standpoint, since the interaction between the individual and the other(s) is actualized on a hermeneutic basis and through a communication channel related to language, fusion of horizon is established within dialogue, but at the same time impenetrable characteristic of the otherness is maintained (Uluocak, 2018: 147).

\section{Fusion of Horizons}

\subsection{Horizon of the Ageist Discourse}

The current discursive gap arose due to the already existing ageist dynamics in the society. Ageism can be traced back to the beginning of humankind, despite it becomes more apparent today. This is mostly because modernization caused elderly to be discredited and disvalued. Unlike in pre-modern agricultural economies where being old means 
having wisdom and experience, in industrial and post-industrial economies old people are seen as insufficient particularly in terms of production. In turn, they are seen as unnecessary in material terms, and can easily be resigned and even expended. Very recently a scientific knowledge, prescribing that old people should stay home and should not contact anyone, has rapidly turned out to be a means of legitimization to produce a negative discourse, which is thought to be both a cause and an effect of ageism, towards elderly.

Through discrimination, an in-group is positioned as stand off from an outgroup with a certain degree of legitimization (Bilgin, 2008: 170). Ageism is a type of discrimination such as sexism, racism etc. It emerged especially after industrialization in which elderly is no more seen as productive in economic terms. Butler (1969: 243) defines ageism as a prejudice having an age group against other age group. Nevertheless, prejudice is practiced mostly towards older people. "Ageism can be described as negative or positive stereotypes, prejudice and/ or discrimination against (or to the benefit of) aging people because of their chronological age" (Iversen, Larsem \& Solem, 2009: 4). As Palmore states (1990) unlike other "-ism"s, ageism, although not broadly been heard yet, has a potential to be experienced by anyone who will reach old age one day. However, by drawing upon the existing literature Iversen et al. (2009) states that ageism, unlike other-isms, is faced with no societal sanctions and thus is generally neglected.

In addition to classical understanding of ageism, a new type of it has recently emerged. Quadagno (1999: 6) calls this, "new ageism" by which old people are approached with a manner of overprotectiveness and concern. By this manner old people are dissuaded to take some risks, even are withheld from the activities they may easily carry out. In addition, positive stereotypes may contribute to what we call new ageism. "Positive stereotypes (e.g., kind, cute, or wise) may appear to be empathetic, but they are actually paternalistic in nature and support ageist behaviors, which can be detrimental to older adults" (Chonody, 2016: 208). Ageism may also appear as infantilization in a different yet the same outlook in social media platforms, as some authors suggest (Gendron et. al., 2016; Levy, et al., 2013). No matter it is negatively or positively, stereotyping and even prejudicing the elderly connotes the idea that the elderly is a group of people who are potentially subject to be discriminated based on their old age.

In fact, ageism may occur at different levels, such as those of micro and macro, and even sometimes at a level where these two interact with each other. At the micro level, ageist attitudes are embodied in individuals' 
discourses posted in social media, the users of which are mostly from the younger age groups. Indeed, statistics from the United States indicates that for instance Twitter is popular among young people aged between 18 and 29 , almost every 4 out of 10 young people are Twitter users. It is rather high when compared to its extensity among the elderly, which is about $7 \%$ (Pew Research Center, 2019).

Secondly it occurs at the macro level, where some administrative measures can be taken such as removing the benches or establishing a phone line to denounce the elderly who break the curfew. Here it is obvious that the discourses at the micro level are aggregated and thus shape the way how to manage limitations towards the elderly. However here the micro level, where how individuals experienced the curfew will be focused rather than how the curfew is administered at the macro level.

Ageist attitudes and behaviours intensifies the idea that there exists a gap between older and younger generations. "Ageism allows the younger generation to see older people as different from themselves; thus they suddenly cease to identify with persons who grow old as human beings" (Butler, 2006: 41). It is widely discussed in the literature that the COVID19 pandemics exacerbated the pre-existing ageism in the society (Previtali et. al., 2020; Meisner, 2020). Ayalon et al. (2020) argued that even "with the pandemic there has been a parallel outbreak of ageism". "The intergroup threat theory suggests that ageism may intensify at times of scarce resources due to the increased threats perceived by the "rest of us" (Stephan \& Stephan, 2017 as cited in Xiang et. al., 2020: 2). As an aspect of apocalyptic demography, due to the scarce resources for an overpopulated world, elderly is perceived as expendable. In parallel with this apocalyptic view, in Twitter in March 2020 \#boomerremover was a trending hashtag. The point is to identify the COVID-19 outbreak with a weapon to remove the baby boomers. For Meisner (2020) the "purpose" of COVID-19 as the "Boomer Remover" is to:

"efficiently address global and domestic overpopulation by targeting older adults and sparing the lives of children, youth, and younger adults; decrease the demand and burden that older adults put on health care and tax systems; remove older adults from society so that more jobs, opportunities, and resources can be provided to younger and healthier people" (Meisner, 2020: 3).

In a study, conducted by Jimenez-Sotomayor and her colleagues (2020) in March 2020, it is found that about one quarter of all tweets concerning COVID-19 and old people are ageist in nature. These tweets are either considered in the category of ridiculous jokes about elderly or they connote 
that elderly is less valuable than youth. The authors also determined that \#boomerremover hashtag was tweeted more than 4000 times within about 2 weeks during their research. In a wider study in terms of representative sample of tweets which have been posted in the first half of 2020, Xiang and her colleagues found a lower rate $(4,8 \%)$ of ridiculous jokes among all. Uysal and Eren (2020) carried out a research between March and June 2020 via Twitter. In the study where the mapped keywords are in Turkish, they found that elderly are sometimes seen as scapegoats of COVID-19, and they are mostly exposed to ridicule, disdain, contempt, offence, hate and threat in tweets about COVID-19.

\subsection{Horizon of The Discourse Against Age-Based Curfew}

Actually rather than raising an objection towards the way how elderly is portrayed in the social media, the objection is concentrated in the curfew which is based on chronological age. It is mostly perceived by the elderly as a discriminatory act towards themselves. Although the discourse developed by the elderly against age-based curfew could not find an audience as large as the young people do since elderly have a decreased access to social media platforms.

First of all, "ageism in social media can partly be explained by the digital divide between younger and older individuals, with most older adults facing limited access to digital technology" (Soto-Perez-de-Celis, 2020: 1). Binark (2020) also argues that the digital divide has continued through the pandemic. It caused older people, who are confined by the lockdown, have a limited access to the means of digital communication. As a result, unequal access to social media platforms renders elderly voiceless; and representation of elderly is confined to the way how they are represented by the younger generation. The consequence of all these is a distorted and misrepresented portrayal of elderly in the society.

Therefore, their opinions were reflected in a set of academic research. As a result, in order to reveal the horizon of the elderly, these sort of research will be drawn upon here.

Dintrans and his colleagues (2020) from Chile found that mandatory quarantine has some mentally and socially negative effects on older people, which contradicts with the "healthy aging" insight developed by the World Health Organization, which is defined in World Report on Ageing and Health as "the process of developing and maintaining the functional ability that enables wellbeing in older age" (WHO, 2015 as cited in ibid).

Another research conducted by Whitehead and Torossian (2021) found that what the most stressful source of the COVID-19 pandemic for the people 
who are 60 and older in the USA is most frequently reported as the restrictions and confinements, including the curfew.

In their research Brooke and Clark (2020) explored the experiences of older people during the first two weeks of household isolation in the UK and in the Republic of Ireland. They found that early reactions of the older people were more positive in that they have taken the opportunity to do the chores which they have not been able to do previously. Perhaps it is partly because of the fact that the research was conducted at the very initial stage of the pandemic and the curfew. The whole findings of this longitudinal research with the later findings would be more meaningful, since the pandemics and accompanying confinements have continued well after the period when this research was carried out.

By drawing upon the data collected from 27 countries all over the world chosen to represent the maximum variation in terms of quality of democracy, economic development and inequality, cultural diversity, etc., Daoust (2020: 4) argued that older people are "not systematically more responsive in terms of prospective self-isolation and willingness to isolate". He also established that they are not the most disciplined age group in terms of compliance with the public preventive measures although this age group is at the highest risk of being hospitalized or mortality.

Ateş (2020) has carried out a field research in which in-depth interviews were conducted during the curfew for the elderly in Turkey, Ankara. In her research voicing the conception of the elderly about the lockdown, she points out that the risk of discrimination and social isolation are commonly emphasized by the older informants.

In a general sense, old people has been the most confined group among all, not only in Turkey but also all over the world during the pandemic. This is mostly because of the fact that they are at the highest risk of morbidity and mortality in case of catching the virus. However as importantly as it is, unlike younger people who are obliged to work or go to school, older people are not obliged to work outside the home. Hence on the condition that older people are isolated at home, neither social nor economic life has not been affected at all, and keeping the elderly at home has become the easiest way to minimize the social contact between human groups differentiated by age.

Social organization of life according to ages and roles related to these ages has become more visible and clear cut in time of the COVID-19 crisis. Older people are supposed to be patient for staying home, however as the time went and the pandemic persisted, older people increasingly began to lose their patience and this situation has been reflected to conventional and 
social media. Moreover, what has also been appeared in the news is that confinement of older people is a kind of violation of human rights since it is a discrimination based on age has been brought to trial by different legal or real entities. This sort of discourse has also been articulated in academic literature as well. For instance, Tunçer (2020: 148) argues that instead of taking COVID-19 measures only for the fragile ones amongst older people, victimization of the whole older group forms a basis of age discrimination.

For the time being, when it has almost a year since the pandemic has been declared, older people are still isolated at home. Based on the ideas developed against curfew and delivered through communication channels, it can be argued that an anti-curfew horizon which is based on antidiscrimination is established. It is because the curfew for the elderly has been associated with agesim (Varışlı \& Gültekin, 2020).

\section{Conclusion}

Given that the COVID-19 pandemic is unforeseen, beside its severity, we can call it a global crisis, in vital, economic and social terms. In order to struggle with the actual and possible loses in all terms, strict measures have been taken. Among all of these measures, due to the fragility of older people, the curfew for them has probably been the most discussed one. The debates have been two-folded. From one perspective -or we can call horizon in Gadamerian sense- younger people advocated that older people should be confined. They mostly utilised digital technology, and social media in particular, while they are developing - mostly ageist- discourses and advocating their ideas about the lockdown decision of their older counterparts. On the other hand, older people's perspective, which is mostly underrepresented throughout the pandemic, formed another horizon. In this sense, this paper is an attempt to interpret older people's curfew by drawing upon the fusion of horizons theory of Gadamer. Only if we approach the same issue from distinct perspectives, may we reach a full meaning of the reality experienced.

Social science is highly sensitive to the discourses developed by the community, hence ageist discourse in social media in time of the COVID19 pandemic aroused an interest for many social scientists and directed them to conduct research on this issue through digital facilities. However, looking only at the representations of elderly during the curfew would be disproportional in that social media is overwhelmed by the younger people, besides some percent of whom are responsible for developing this ageist discourse. To counter-balance the argument, the elderly should be enabled to express their opinions and sentiments. In this paper some literature was incorporated to give voice to the elderly who might have faced the most 
difficulty as being socially isolated at homes. Nevertheless, it should be recognized that further applied studies are required in order to shed light especially on the ways how old people have been experiencing the restrictions of the curfew.

\section{References}

Altın Z. (2020). Covid-19 Pandemisinde yaşlılar. Tepecik Eğit. ve Araşt. Hast. Dergisi. 30 (Ek say1), s.49-57.

Andersen, J. (2020). Understanding and Interpreting Algorithms: Toward a Hermeneutics of Algorithms, Media, Culture \& Society 42(7-8), s.1479-1494.

Ateş Ö. (2020). COVID-19 Lockdown: The Unspoken Toll on The 65+ Community in Turkey, Working With Older People, 24(4), s.303311.

Ayalon, L., Chasteen A., Diehl, M., Levy, B.R., Neupert, S. D., Rothermund K., Tesch-Römer, C. \& Wahl, H-W. (2021). Aging in Times of the COVID-19 Pandemic: Avoiding Ageism and Fostering Intergenerational Solidarity, J Gerontol B Psychol Sci Soc Sci, 76(2), e49-e52.

Bilgin, N. (2008). Sosyal Psikoloji, İzmir: Ege Üniversitesi Basımevi.

Binark, M. (2020). Eşitsizliklerin Yeniden Tezahürü: Dijital Eşitsizlikler ve Yaşlı Bireyler, Cogito, (98), s.165-174.

Brooke J. and Clark M. (2020). Older People's Early Experience of Household Isolation And Social Distancing During COVID-19, Journal of Clinical Nursing, 2, s.4387-4402.

Butler, R. (1969). Ageism: Another Form of Bigotry, The Gerontologist 9(4), s.243-246.

Chonody, J. M. (2016). Positive And Negative Ageism: The Role Of Benevolent And Hostile Sexism. Affilia: Journal of Women \& Social Work, 31(2), s.207-218.

Daoust J. F, (2020). Elderly People and Responses to COVID-19 in 27 Countries, PloS One, 15(7), s.0235590.

Dintrans P. V., Browne, J. and Madero-Cabib I. (2020). It Is Not Just Mortality: A Call From Chile for Comprehensive COVID-19 Policy Responses Among Older People, Journals of Gerontology: Social Sciences, 10(10), s.1-6. 
Dubow E.F., Huesmann L.R. \& Boxer, P. (2003). Theoretical and Methodological Considerations in Cross-Generational Research on Parenting and Child Aggressive Behavior, Journal of Abnormal Child Psychology, 31(2), s.185-192.

Gadamer, H. G. (2004). Truth and Method, London: Contiuum Publishing.

Gendron T. L., Welleford E. A., Inker J. and White J. T. (2016). The Language of Ageism: Why We Need to Use Words Carefully, The Gerontologist, 56(6), s.997-1006.

Ellerich-Groppe, N., Pfaller L. \& Schweda M. (2021). Young for old-old for young? Ethical perspectives on intergenerational solidarity and responsibility in public discourses on COVID-19, European Journal of Ageing https://doi.org/10.1007/s10433-021-00623-9.

Jimenez-Sotomayor M. R., Gomez-Moreno, C. and Soto-Perez-de-Celis E. (2020). Coronavirus, Ageism and Twitter: An Evaluation of Tweets about Older Adults and COVID-19, The American Geriatrics Society, 68, s.1661-1665.

Jordan R. E., Adab P. and Cheng K. K. (2020). Covid-19: Risk Factors For Severe Disease And Death, British Medical Journal, 2020, 368, s.m1198.

Köroğlu, S.A., 2015, "Literatür Taraması Üzerine Notlar ve Bir Tarama Tekniği”, GIDDB Dergi, Sayı:1, s.61-69.

Larsen L., Solem E. P. and Iversen T. N. (2009). A Conceptual Analysis of Ageism, Nordic Psychology, 61(3), s.4-22.

Leung, L. (2013). Generational differences in content generation in social media: The roles of the gratifications sought and of narcissism, Computers in Human Behavior, 29(3). s.997-1006,

Levy B. R, Chung P H., Bedford T. and Navrazhina K. (2013). Facebook as a Site for Negative Age Stereotypes, The Gerontologist, 54(2), s.172-176.

Meisner B. A. (2020). Are You OK, Boomer? Intensification of Ageism and Intergenerational Tensions on Social Media Amid COVID-19, Leisure Sciences, Special Issue: Leisure In The Time Of Covid19. A Rapid Response, s.1-6.

Murray A. (2011) Mind the gap: technology, millennial leadership and the cross-generational workforce, The Australian Library Journal, 60(1). s.54-65. 
Napoli, A. (2014). Social media use and generational identity: Issues and consequences on peer-to-peer and cross-generational relationships an empirical study, Participations. Journal of Audience and Reception Studies, 11(2), s.182-206.

Palmore E. (1990). Ageism: Negative and Positive. New York: Springer Publishing.

Palmore, E. (2006). Ageism, (in) The Encyclopedia of Ageing, 4th Ed., Vol: I: A-K. (Ed. in Chief: R. Schulz), New York: Springer Publishing.

Pew Research Center (2021). Social Media Act Sheet, https://www.pewinternet.org/fact- sheet/social-media/. 2019. [accessed on March 2, 2021].

Previtali, F., Allen L. D. \& Varlamova, M. (2020). Not Only Virus Spread: The Diffusion of Ageism during the Outbreak of COVID-19, Journal of Aging \& Social Policy, 32(4-5), s.506-514.

Roebuck D.B., Smith D.N. \& Haddaoui, T.E. (2013). Cross-Generational Perspectives on Work-Life Balance and its Impact on Women's Opportunities for Leadership in the Workplace, Advancing Women in Leadership Vol. 33. s.52-62.

Quadagno, J. (1999). Aging and the Life Course, USA: McGraw-Hill College.

Soto-Perez-de-Celis, E. (2020). Social Media, Ageism, And Older Adults During The COVID-19 Pandemic, EClinicalMedicine, Commentary. s.29-30.

Tatar, B. (2018). Felsefî Hermenötük ve Yazarın Niyeti, İstanbul: Vadi Yayınlar1.

Taşdelen, B. (2020). COVID-19 salgın sürecinde yaşlılağa bakış: 280 karakter yaşlılar hakkında ne söylüyor?. Turkish Studies, 15(6), 877-891.

Tuna Uysal, M. ve Tan Eren G. (2020). Discrimination Against the Elderly on Social Media During the COVID-19 Epidemic: Twitter Case, Turkish Studies, 15(4), s.1147-1162.

Tunçer, M. (2020) Kriz Döneminde Yaşçılık: Yeni Mücadele Alanları, Cogito, (98), s.144-152. 
Uluocak, Ş. (2018). Bilgi Sosyolojisi Açısından Gerçekliğin Sosyal İnşası ve Gadamer Hermeneutiği, Dokuz Eylül Üniversitesi Edebiyat Fakültesi Dergisi, 5(1), s.135-157.

Varışlı, B., Gültekin, T. (2020). Yaşlı ayrımcılığının pandemi hali: COVID-19 sürecinde kuşaklararası etkileşimin dönüşümü. Turkish Studies, 15(4), s. 1227-1237.

Vessey D. (2009) Gadamer and the Fusion of Horizons, International Journal of Philosophical Studies, 17(4), s.531-542.

Whitehead B. R. and Torossian E. (2021). Older Adults' Experience of the COVID-19 Pandemic: A Mixed-Methods Analysis of Stresses and Joys, The Gerontologist, 61(1), s. 36-47.

Xiang X, Lu X, Halavanau A, Xue J, Sun Y, Lai P. H. L. and Wu Z. (2020). Modern Senicide in the Face of a Pandemic: An Examination of Public Discourse and Sentiment About Older Adults and COVID19 Using Machine Learning, Journals of Gerontology: Psychological Sciences, 10(10), s.1-11.

Zervides, S. \& Knowles, A. (2007). Generational Changes in Parenting Styles and the Effect of Culture, E-Journal of Applied Psychology, 3(1), s. 65-75. 